\title{
PERKEMBANGAN FUNGSI PRAGMATIK PADA ANAK USIA 2,5 TAHUN (STUDI KASUS PADA AZZA AQILA JIHAN SYUASABITHA)
}

\section{THE DEVELOPMENT OF PRAGMATIC FUNCTION IN CHILDREN AGE 2.5 YEARS (CASE ST UDY ON AZZA AQILA JIHAN SY UASABITHA)}

\author{
Ali Kusno \\ Kantor Bahasa Kalimantan Timur \\ Jalan Batu Cermin 25, Sempaja Utara, Samarinda \\ Pos-el: alikusnolambung@gmail.com
}

\begin{abstract}
A bstract
Thegdden ageof kid wasa sensitiveperiod Duringthis period, thekid was speiallyreeciungthestimilant fromthe enironment. Thepeiod of kid'slangragedeudqpmet vasvarias dependent on thedharadeistics Thissturyredateel tothefunctiondedepment of kid'slangrage Theexamplecasetothegid 2,5yearsdd, AzzaAqilaJihanSyrasabitha (Jihan). Jihan was grovingin thefamilyeniromment and dildcaing Thekid'slangragevas deudquingquidkly. The usage of langragevas dencteel toJihan'sinteraction withfamilymembers Colleting data mthodin thisstudy was the dbservation Thesubjet in this study was thedild's author. This study aimed to describethededqpment of Jihan's speech as dild2,5 years dd based on thelanguagefundion grapingaccordingtoMA. KHalliday. Theresult of the sturyshowedthekidcan applyall of languagefundionusage Thosearetheinstrumetal, theregulatory, theinteradional, thepessnal, thehenistic, theimagnative, and therepresentational. Thereore, shevasinterpreed has theabilityabove averagethedildren thesameage Theadievenet wasinfluened bybidogical factars (parentswhohevegoodlangrage skills) andsoial eniromment (in thehouse, in theshod, andsoon) which can stimulatejihan'slanguagedediqument
\end{abstract}

Keyw ords: deddqment, pragmatical Funtion, kidslanguage

\begin{abstract}
Abstrak
Masa keemasan anak merupakan periode sensitif (sensitivepeiods). Selama masa tersebut anak secara khusus mudah menerima stimulus-stimulus dari lingkungan. Tempo perkembangan bahasa anak cenderung variatif tergantung karakteristik anak. Penelitian ini berhubungan dengan perkembangan fungsi bahasa anak. Contoh kasus, Azza Aqila Jihan Syuasabitha (Jihan) anak perempuan yang berusia 2,5 tahun. Jihan besar dalam lingkungan keluarga dan taman penitipan anak. Perkembangan fungsi bahasanya pesat. Pemakaian bahasa dikhususkan pada interaksi Jihan dengan anggota keluarga. Pengumpulan data dalam penelitian dengan teknik pengamatan berperan serta. Subjek penelitian ini adalah anak penulis sendiri. Penelitian ini bertujuan untuk mendeskripsikan perkembangan tuturan Jihan sebagai anak yang berusia 2,5 tahun berdasarkan pengelompokan fungsi bahasa menurut M.A.K Halliday. Hasil penelitian menunjukkan anak itu mampu menerapkan keseluruhan fungsi penggunaan bahasa, yakni instrumental, regulatoris/ dogmatis, interaksional, personal, heuristik, imajinatif, dan representasional. D engan demikian, dapat diinterpretasikan bahwa anak itu memiliki kemampuan di atas rata-rata anak seumur dia. Pencapaian tersebut dipengaruhi oleh faktor biologis (orang tua yang memang memiliki kemampuan berbahasa yang baik) dan lingkungan sosial (di rumah, sekolah, dan tempat lain).
\end{abstract}

Kata Kunci: perkembangan bahasa, fungsi penggunaan bahasa, bahasa anak 


\section{PENDAHULUAN}

Anak mengalami perkembangan luar biasa pada usia dini, yakni antara usia 0-9 tahun. Perkembangan anak tersebut melalui tahapan yang progresif dan berkesinambungan dalam diri individu sejak lahir sampai meninggal. Pengertian perkembangan adalah perubahan-perubahan yang dialami individu atau organisme menuju tingkat kedewasaan atau kematangan (maturation) yang berlangsung secara sistematis, progresif, dan berkesinambungan, baik menyangkut fisik (jasmaniah) maupun psikis (rohaniah) (Yusuf, 2009: 15). Anak pada usia dini berada dalam masa keemasan sepanjang rentang usia perkembangan manusia.

Montesori dalam Yuliani Nuraini Sujiono dan Bambang Sujiono (Yusuf, 2009: 15) mengungkapkan bahwa masa keemasan anak merupakan periode sensitif (sensitiveperiod). Selama masa tersebut anak secara khusus mudah menerimastimulusstimulus dari lingkungan. Anak siap melakukan berbagai kegiatan dalam rangka memahami dan menguasai lingkungan. Variasi lingkungan anak berinteraksi dapat menunjang perkembangan bahasanya. Yusuf (2009: 34) mengungkapkan bahwa perkembangan memiliki prinsip-prinsip tertentu. Proses perkembangan tidak pernah berhenti (neer ending process). Semua aspek perkembangan saling memengaruhi. Perkembangan itu mengikuti pola atau arah tertentu. Selain itu, perkembangan terjadi pada tempo tertentu yang berlainan. Setiap fase perkembangan mempunyai ciri khusus. Setiap individu yang normal akan mengalami tahapan/ fase perkembangan tersebut.

Tempo perkembangan bahasa anak cenderung variatif bergantung pada karakteristik anak. Pada usia 2-3 tahun, anak mengalami tahap linguistik kalimat dua kata. Sebagian anak perkembangannya sesuai dengan tahapan tersebut. Sebagian anak yang lain terlambat dalam penguasaan bahasanya. Namun, ada juga anak yang memiliki perkembangan bahasa yang lebih cepat dari usianya.
Contoh kasus anak yang memiliki perkembangan bahasa yang lebih cepat dari usianya adalah Azza A qila Jihan Syuasabitha (Jihan). Jihan merupakan seorang anak perempuan berusia 2,5 tahun. Anak itu lahir prematur pada usia kandungan 8,5 bulan. Anak itu sudah matang fungsifungsi fisik dan psikisnya pada usia 2,5 tahun. Anak itu tinggal di lingkungan keluarga besar, terdiri atas ayah (orang tua), ibu (orang tua), papa (kakek), mama (nenek), mas(paman), bunda(nenek), dan nenk (nenek buyut). Pada usia 1- 3 bulan anak ini dalam pengasuhan ibu (orangtua). Pada usia 3-7 bulan anak itu diasuh oleh pembantu di rumah karena ibu bekerja. Pada usia 7 bulan sampai dengan 2,5 tahun (saat penelitian dilakukan) masuk di Taman Penitipan Anak (TPA) Sanggar Rubinha Samarinda yang memiliki 28 siswa. G uru dan pengasuh di taman penitipan anak tersebut sebanyak tujuh orang. Selama di penitipan anak, anak itu banyak mendapatkan stimulasi melalui kegiatan belajar, bermain, dan lagu-lagu anak. Pada saat di lingkungan rumah, anak ini berinteraksi dengan semua anggota keluarga. Selain itu, orang tua anak itu juga sering memberikan stimulasi untuk berinteraksi dengan lingkungan sosial yang lebih variatif, misalnya lingkungan perpustakaan, mal, hotel, pasar, dan lingkungan kampus.

Pada usia 2,5 tahun Jihan memiliki perkembangan bahasa yang terbilang cepat. Selain perkembangan bahasa yang baik secara kuantitas, perkembangan fungsi penggunaan bahasa (pragmatik) anak itu juga berkembang dengan baik. Penelitian ini bertujuan mendeskripsikan perkembangan tuturan anak itu sebagai anak yang berusia 2,5 tahun berdasarkan pengelompokan fungsi pragmatik dalam berbagai situasi tuturan.

Masa perkembangan fungsi pragmatik Jihan pada usia yang ke-2,5 tahun dapat dipahami karena berada pada fase keemasan. Menurut Montessori (2015), usia keemasan merupakan 
masa anak mulai peka menerima berbagai stimulasi dan upaya pendidikan dari lingkungan, baik sengaja maupun tidak disengaja. Pada masa peka inilah terjadi pematangan fungsi-fungsi fisik dan psikis sehingga anak siap merespons dan mewujudkan semua tugas perkembangan yang diharapkan muncul dalam pola perilakunya sehari-hari.

Catron dan Allen dalam Sujiono dan Bambang Sujiono (Sujiono, 2010: 22) menyebutkan bahwa terdapat enam aspek perkembangan anak usia dini, yaitu kesadaran personal, pengembangan emosi, membangun sosialisasi, pengembangan komunikasi, kognisi, serta kemampuan motorik sangat penting dan harus dipertimbangkan sebagai fungsi interaksi. Keenam aspek perkembangan tersebut saling terkait dan memengaruhi terhadap perkembangan anak pada usia dini.

Pada umumnya, anak usia dini memandang segala sesuatu sebagai satu kesatuan yang utuh (khaffah) sehingga pembelajarannya masih bergantung pada objek konkret, lingkungan, dan yang dialaminya (Mulyasa, 2012: 32). Anak belajar dari hal-hal yang nyata dan dapat dilihat. Lingkungan di sekitar anak menjadi sarana efektif sebagai objek belajar. Peran guru dan orang tua memberikan lingkungan yang positif bagi perkembangan anak. Selain itu, pengalaman nyata pada anak sendiri bisa digali dalam proses pembelajaran.

Perolehan bahasa anak-anak dapat dikatakan mempunyai ciri kesinambungan, memiliki suatu rangkaian kesatuan, yang bergerak dari ucapan satu kata sederhana menuju penggabungan kata yang lebih rumit (sintaksis) (Tarigan, 2011: 6). Kemajuan kemampuan berbahasa anak berjalan seiring dengan perkembangan fisik, mental, intelektual, dan sosialnya. Menurut Tarigan (2011) ada dua persyaratan dasar yang memungkinkan anak dapat memperoleh kemampuan berbahasa, yaitu potensi faktor biologis yang dimiliki sang anak serta dukungan sosial yang diperolehnya. Faktor biologis anak yang berkenaan dengan pemerolehan dan pengembangan bahasa merupakan modal utama. Selanjutnya, potensi tersebut dapat berkembang baik dengan ditunjang dukungan sosial yang dapat menstimulasi perkembangan bahasa anak.

M. Scaerlaekens (Mar'at, 2011: 61) membagi fase-fase perkembangan bahasa anak dalam empat periode. Perbedaan fase-fase tersebut berdasarkan ciri-ciri tertentu yang khas pada setiap periode. Adapun periode-periode tersebut sebagai berikut: a. Periode prelingual (usia $0-1$ tahun)

b. Periode lingual dini (1-2,5 tahun)

c. Periode diferensiasi (usia 2,5-5 tahun)

d. Perkembangan bahasa sesudah usia 5 tahun.

Khusus periode diferensiasi (usia 2,5-5 tahun) ialah kemampuan anak dalam mengadakan diferensiasi dalam penggunaan kata-kata dan kalimat-kalimat. Secara garis besar ciri umum perkembangan bahasa pada periode ini sebagai berikut (Mar'at, 2011: 66-67

a. Pada akhir periode secara garis besar anak telah menguasai bahasa ibunya, artinya hukumhukum tata bahasa yang pokok dari orang dewasa telah dikuasai.

b. Perkembangan fonologi bisa dikatakan telah berakhir.

c. Perkembangan bahasa berkembang, baik kuantitatif maupun kualitatif.

d. Kata benda dan kata kerja mulai terdiferensiasi dalam pemakaiannya, ditandai dengan dipergunakannya kata depan, kata ganti, dan kata kerja bantu.

e. Fungsi bahasa untuk komunikasi betul-betul mulai berfungsi, anak sudah dapat mengadakan konversi dengan cara yang dapat dimengerti oleh orang dewasa.

f. Persepsi anak dan pengalamannya tentang dunia luar mulai ingin dibaginya dengan orang lain, dengan cara memberikan kritik, bertanya, menyuruh, memberi tahu, dan lain-lain. 
g. Mulai terjadi perkembangan di bidang morfologi, ditandai dengan munculnya kata jamak, perubahan akhiran kata benda, dan perubahan kata kerja.

Clark \& Clark (dalam Tarigan, 2011: 37) mengatakan bahwa anak-anak membangun struktur dan fungsi pada waktu yang bersamaan. Anak mempelajari banyak fungsi untuk memperluas pemakaian tempat berbagai struktur diterapkan. Oleh karena itu, situasi tutur dengan variasi lingkungan interaksi, sangat bagus untuk membangun struktur dan fungsi bahasa anak.

Anak dapat berinteraksi dengan orang lain yang berbeda dengan latar belakang kehidupan: dalam kelas, kelompok bermain, di perpustakaan, di rumah teman, dan di lingkungan rumah tangga (Tarigan, 2011: 37-38). D alam dunia sosial yang lebih luas tersebut, bahasa anak harus mampu melayani beberapa fungsi baru dan harus lebih efektif melayani beberapa fungsi umum. Dunia interaksi yang luas, situasi, dan maksud yang lebih beraneka ragam justru mendorong bahasa anak menjadi tersesuaikan secara luas (Brown, dalam Tarigan, 2011: 38). Anak dapat belajar menyesuaikan diri dengan lingkungan interaksi yang beragam.

Perkembangan pragmatik atau penggunaan bahasa merupakan hal paling penting dibanding perkembangan aspek bahasa lainnya (fonologi, morfologi, sintaksis, dan semantik). Ada tujuh faktor penentu yang perlu dipahami anak, yaitu (1) kepada siapa berbicara (2) untuk tujuan apa, (3) dalam konteks apa, (4) dalam situasi apa, (5) dengan jalur apa, (6) melalui media apa, (7) dalam peristiwa apa (Tarigan dalam Pusat Pengembangan Profesi Pendidik, 2012: 22).

Ketujuh faktor penentu komunikasi tersebut berkaitan erat dengan fungsi pragmatik (penggunaan bahasa) yang dikemukakan oleh M.A.K. Halliday: instrumental, regulator, interaksional, personal, imajinatif, heuristik, dan informatif
(Pusat Pengembangan Profesi Pendidik, 2012: 22).

a. Fungsi instrumental: penggunaan bahasa untuk mencapai suatu hal yang bersifat materi seperti makan, minum, dan sebagainya.

b. Fungsi regulatoris/ dogmatis: penggunaan bahasa untuk memerintah dan perbaikan tingkah laku.

c. Fungsi interaksional: penggunaan bahasa untuk saling mencurahkan perasaan pemikiran antara seseorang dan orang lain.

d. Fungsi personal: seseorang menggunakan bahasa untuk mencurahkan perasaan dan pikiran.

e. Fungsi heuristik: penggunaan bahasa untuk mengungkap tabir fenomena dan keinginan untuk mempelajarinya. Contoh: Mengapa itu terjadi?

f. Fungsi imajinatif : Penggunaan bahasa untuk mengungkapkan imajinasi seseorang dan gambaran-gambaran tentang penemuan seseorang dan tidak sesuai dengan realita (dunia nyata).

g. Fungsi representasional: pengunaan bahasa untuk menggambarkan pemikiran dan wawasan serta menyampaikannya pada orang lain.

D alam tesis AnalisisPragnatik tehadapTuturan Anak UsiaDuaTahun(Stud Kasuspada ShihabFatin Alvan) (Sudartinah, 2010) menunjukkan bahwa jenis tindak tutur yang paling banyak dijumpai pada tuturan anak usia dua tahun adalah tindak representatif dan direktif. Tindak ekspresif dan komisif sudah terdapat pada tuturan anak meskipun frekuensinya masih relatif kecil dibandingkan tindak representatif dan direktif. Tindak tutur deklaratif sama sekali belum dijumpai pada tuturan anak usia dua tahun. Bentuk tuturan langsung lebih sering digunakan oleh anak usia dua tahun 
ketika bertutur dibandingkan bentuk tuturan tidak langsung. Di balik kompleksitas muatan ilokusioner yang terkandung dalam tuturan anak usia dua tahun, terdapat beberapa kesederhanaan, antara lain dalam hal struktur, pemakaian kata, dan penggunaan gestur dan intonasi. Peran yang diberikan oleh anak dalam membangun sebuah percakapan adalah dengan cara menginisiasi topik dalam percakapan itu. D alam mengembangkan sebuah percakapan yang topiknya telah diinisiasi oleh mitra tuturnya, tuturan anak berkontribusi dalam upaya pencapaian struktur lengkap percakapan.

Pinnel dalam Modul Karakteistik Pekenbangan Bahasa Anak (Pusat Pengembangan Profesi Pendidik, 2012: 22) mengungkapkan penggunaan fungsi bahasa di SD kelas awal, umumnya anak masih sebatas menggunakan fungsi interaksional (untuk berkomunikasi) dan jarang menggunakan fungsi heuristik (mengunakan bahasa untuk mencari ilmu pengetahuan saat belajar dan berbicara dalam kelompok kecil).

Dale (Mar'at, 2011: 76) berpendapat bahwa pengukuran kemampuan berbahasa dan perkembangan bahasa anak mempunyai beberapa fungsi, di antaranya untuk riset kemajuan anak selama normal dengan tujuan eksplorasi terhadap efek dari berbagai faktor lingkungan. Pengukuran kemampuan dan perkembangan bahasa anak dapat mendeteksi kemajuan anak. Hal itu juga dapat berfungsi untuk mengetahui pengaruh berbagai faktor lingkungan terhadap perkembangan kemampuan dan perkembangan bahasa anak. Pengukuran perkembangan bahasa bukan suatu tes, melainkan suatu pengukuran kemampuan bahasa secara teoretis.

Menurut Mar'at (2011: 76) cara pengukuran perkembangan bahasa dilakukan dengan mengumpulkan data-data bahasa yang berupa tuturan spontan (spontaneus speech). Tuturan spontan sebagai sumber data yang akan dianalisis merupakan tuturan alami dalam interaksi sehari-hari.

\section{METODE PENELITIAN}

Metode yang digunakan dalam penelitian ini adalah metode penelitian kualitatif yang bersifat deskriptif. Menurut Moleong (1994: 6) metode penelitian kualitatif merupakan prosedur penelitian yang menghasilkan data deskriptif berupa kata-kata tertulis dan lisan tentang sifat individu, keadaan, gejala dari kelompok tertentu yang dapat diamati.

Penelitian ini berhubungan dengan perkembangan fungsi pragmatik Jihan di lingkungan keluarga. Pemakaian bahasa dikhususkan pada interaksi Jihan dengan anggota keluarga. Pengumpulan data dalam penelitian ini dengan teknik pengamatan berperan serta. Menurut D enzin (Mulyana, 2010: 163) pengamatan berperan serta adalah strategi lapangan dengan responden dan informan, partisipasi, observasi langsung, dan introspeksi. D alam hal ini, objek penelitian adalah Jihan, anak penulis, sehingga memberikan keleluasaan melakukan pengamatan.

D asar yang dipakai dalam penentuan tuturan dan dijadikan data, di antaranya variasi penggunaan fungsi pragmatik Jihan. Teknik analisis data menggunakan model interaktif, seperti yang dikemukakan Miles \& Huberman ( 2007: 19-20) yang terdiri atas tiga komponen analisis, yaitu reduksi data, sajian data, dan penarikan simpulan atau verifikasi. Aktivitas ketiga komponen itu dilakukan dalam bentuk interaktif dengan proses pengumpulan data.

\section{PEMBAHASAN}

Jihan memiliki perkembangan bahasa yang terbilang cepat pada usianya yang baru 2,5 tahun. Perkembangan itu salah satunya dalam fungsi pragmatik (penggunaan bahasa). Menarik untuk menganalisis penggunaan bahasa anak itu dalam keseharian terutama saat berinteraksi dengan anggota keluarga. Dalam pembahasan ini analisis 
interaksi dikelompokkan berdasarkan fungsi pragmatik tuturan yang disampaikan. Adapun fungsifungsi pragmatik tersebut berupa instrumental, regulatoris/ dogmatis, interaksional, fungsi personal, fungsi heuristik, fungsi imajinatif, fungsi representasional. Berikut ini analisis data perkembangan bahasa Jihan pada usia 2,5 tahun terkait dengan perkembangan fungsi-fungsi pragmatik tersebut.

\section{Fungsi Instrumental}

Fungsi instrumental merupakan penggunaan bahasa untuk mencapai suatu hal yang bersifat materi, seperti makan, minum, dan sebagainya. Fungsi ini bisa dikategorikan sebagai fungsi dasar terutama bagi anak yang masih dalam taraf awal belajar berbahasa. Fungsi ini sering digunakan anak dalam interaksi dengan lingkungan keluarga. Berikut ini analisis fungsi instrumental tuturan anak dalam lingkungan keluarga.

1) Jihan: Ayah, sudah habis (sambil menyodorkan botd susu).

Ayah: Mash mau? (sankil oggh.oghhan).

Jihan: Iya (menganggkk).

Ayah: Ya sudah Sini ayah bikinkan

Informasi tuturan:

Tuturan antaraJihan (anak) dan Ayah (bapak/ orangtua) saat menjelang tidur. Anak memiliki kebiasaan minum susu dua botol sebelum tidur. Satu botol susu sudah dihabiskannya dan meminta dibuatkan lagi susu yang kedua sebagai pengantar tidur.

Seperti tuturan dalam data (1) tersebut, anak itu telah mengalami perkembangan pragmatik atau penggunaan bahasa fungsi instrumental. Dalam tuturan tersebut anak itu menggunakan tuturan Ayah, sudah habis Berdasarkan konteks tersebut dapat dipahami bahwa yang dimaksud tuturan anak itu seperti dalam data (1) adalah meminta ayahnya (orang tua) membuatkan susu lagi. Anak itu mengggunakan fungsi intrumental tuturan agar dibuatkan susu. Fungsi instrumental tuturan di atas menyatakan bahwa anak masih haus dan meminta dibuatkan lagi. Tuturan tersebut dalam konteks tindak tutur termasuk ke dalam tindak ilokusi yang berfungsi untuk meminta orang tua membuatkan susu lagi.

Perkembangan fungsi instrumental anak juga terdapat dalam interaksi berikut ini.

1) Jihan: Jihan ndak bisa. Ndak bisa masukin (mencoba memakai sepatu)

Ilar: Bisa itu Sudah gedemasak ndak bisa.

Jihan: Ndak bisa! (sambil membetak jengkd)

Ibu: E.. Kdk bentak Ibu.

Jihan: Ini nah, susah

Ibu: Bilang apa sama Ibu?

Jihan: Tdongllou

Informasi tuturan:

Tuturan antara Jihan dan Ibu yang mengungkapkan bahwa Jihan belum bisa memakai sepatu sendiri.

Seperti tuturan dalam data (2) tersebut, anak telah menggunakan tuturan pragmatik yang ditanggapi mitra tutur (ibu) bahwa apa yang dilakukannya masih memerlukan bantuan yang juga berfungsi instrumental. Pada tuturan tersebut, anak itu menggunakan tuturan Jihan ndak bisa, ndak bisa masukin yang sebenarnya meminta bantuan orang tua untuk membantu memakaikan sepatu. Tuturan tersebut berkaitan dengan tuturan selanjutnya, yakni tuturan ini mah susah Tuturan tersebut juga termasuk tindak ilokusi yang berfungsi menginformasikan ketidakbisaan memakai sepatu yang dipergunakan untuk meminta ibu (orang tua) membantu memakaikan sepatu.

Dalam dua data tersebut ditunjukkan bahwa anak itu sudah dapat menggunakan dan menempatkan fungsi instrumental dalam interaksi dengan baik. Anak itu mampu menggunakan fungsi instrumental dengan baik terkait dengan kebutuhannya untuk mencapai suatu hal yang bersifat materi, 
seperti makan, minum, dan sebagainya. Anak dalam menggunakan fungsi instrumental kepada mitra tutur yang dewasa dapat dikaitkan dengan kesantunan berbahasa. Oleh karena itu, kemampuan anak usia 2,5 tahun itu menggunakan tuturan yang berfungsi instrumental sekaligus termasuk tindak ilokusi sebagai proses belajar dari mitra tutur (orang tua). Anak menjadikan orang tua sebagai model dalam mempelajari gaya tutur. D engan demikian, orang tua selayaknya menjadi contoh yang baik bagi anak dalam belajar berbahasa, khususnya instrumental yang tetap mengedepankan kesantunan.

\section{Fungsi Regulatoris/ Dogmatis}

Fungsi regulatoris/ dogmatis merupakan penggunaan bahasa untuk memerintah dan memperbaiki tingkah laku. Berikut ini interaksi yang menggambarkan penggunaan fungsi dogmatis anak dalam beragam interaksi.

2) Ayah: Jihan, Onydk Ayah arit ya? Jihan: Jangan (merengk)

Ayah: Ni Ayah aubit-abit. Gemes (purapura memalit)

Jihan: Nakk! Siri! Jangan Ayah kasihan Onydk. (medaut dan menglus bonkka kesayangannya).

Informasi tuturan:

Tuturan antara Ayah dan Jihan. Ayah bercanda mencubit boneka Onyek (Monyet) kesayangan Jihan.

Seperti dalam data (3) tersebut, anak itu telah menggunakan tuturan yang menunjukkan perkembangan pragmatik fungsi regulatoris/ dogmatis. Secara pragmatik apa yang dilakukan ayah (orang tua) ditanggapi mitra tutur (anak) dengan menyatakan larangan (tindakan ilokusi). Anak melarang orang tua mencubit boneka kesayangannya dengan tuturan ndak! Sini! Jangan Ayah, kashan Onykk. Tuturan tersebut mengandung fungsi regulatoris memerintahkan orang tua untuk tidak mencubit boneka kesayangannya.
Berikut ini tuturan dalam interaksi anak di lingkungan keluarga yangjuga menunjukkan penggunaan fungsi regulatoris/ dogmatis untuk mengungkapkan perintah dan memperbaiki tingkah laku.

3) Jihan: Ibu kast. (menunjukkan DVD animasi)

Ibu : Iya kast. (prapura tidak paham).

Jihan: Jihan mau ini. Jihan mau nonton Adit.

Ibu : Bentar nah Jihan Ibu lag notton Tad d peritipan kan Jihan sudah nonton

Jihan: Tapi Jihan mauini. Nyalakan Ilau (Sanbil memenet DVD Playe).

Ilou : Heh Siri. Bilangapa?

Jihan: Tdonglbu (Sambil senyum).

Informasi tuturan:

Tuturan antara Jihan dengan Ibu untuk menonton film animasi.

Tuturan dalam data (4) tersebut menunjukkan anak itu telah mengalami perkembangan bahasa fungsi regulatoris untuk mengungkapkan perintah dan memperbaiki tingkah laku. Hal itu tampak dalam tuturan anak, Jihan mau ini, Jihan mau nonton Adit, lalu tuturan berikutnya tapi Jihan mau ini, nyalakanIluu Tuturan tersebut mengandung fungsi regulatoris memerintahkan Ibu (orang tua) untuk memutar DVD animasi Adit. Tuturan tersebut sekaligus menunjukkan anak itu telah mampu menerapkan tindak tutur perlokusi karena tuturan ibu kast memiliki daya pengaruh terhadap ibu (orang tua) untuk melakukan tindakan membantu memutarkan kaset DVD.

Penggunaan fungsi regulatoris/ dogmatis yang dituturkan anak seperti dalam kedua data tersebut memperlihatkan kemampuan anak dalam berbahasa. Tuturan anak itu juga memperlihatkan kemampuan menyatakan apa yang dimaksudkan tanpa melalui kata-kata verbal, tetapi sudah mampu dipahami dan ditanggapi mitra tutur. Hal itu membuktikan bahwa anak usia 2,5 tahun mampu menggunakan fungsi regulatoris/ dogmatis dalam 
mengungkapkan perintah dan memperbaiki tingkah laku dengan baik.

\section{Fungsi Interaksional}

Fungsi interaksional adalah penggunaan bahasa untuk saling mencurahkan perasaan pemikiran antara seseorang dan orang lain. Apabila dicermati dengan baik, anak telah menggunakan fungsi interaksional tersebut dalam interaksi sehari-hari seperti dalam tuturan berikut ini.

4) Ayah: Jihan mau jad apa?,

Jihan: Bos Boshotd. Bosmall juga. Hotdnyabesar betul.

\section{Ayah: Ayah bodeh tidur di hotd Jihankah?}

Jihan: Bdeh Sama Ilou Sama Papa Mama. Teus

\section{Mas juga.}

Informasi tuturan:

Tuturan antara Ayah dan Jihan. Ayah menstimulasi Jihan terkait penanaman jiwa kewirausahaan. Sejak dini Jihan sudah diarahkan untuk menjadi pengusaha/ bos. Keinginan Jihan menjadi seorang bos hotel dan mal karena kekagumannya waktu jalan-jalan ke mal dan hotel.

Berdasarkan tuturan dalam data (5) tersebut, anak itu telah mengalami perkembangan bahasa fungsi interaksional. Anak mampu menggunakan bahasa untuk saling mencurahkan perasaan pemikiran antara seseorang dan orang lain. Anak itu, saat ditanya perihal cita-cita, menuturkan Bos, Bos hote, Bos mall juga, Hotenya besar betul. Tuturan lanjutan Bdeh, sama Ibu, sama PapaMama, terus Mas juga Tuturan antara anak dan orang tua tersebut memperlihatkan fungsi interaksional bahasa anak. Tuturan anak tersebut juga dapat dikategorikan sebagai tindak lokusi karena mampu menyatakan sesuatu sekaligus informatif.

Tuturan lain yang juga menunjukkan penggunaan fungsi interaksional untuk saling mencurahkan perasaan pemikiran anak dan orang lain terlihat dalam data berikut ini.
5) Jihan: Mama kaki Jihan sakit.

Mama : Kenapa Nak?

Jihan: Gigit semit nah Ma. (sambil mempelihatkan bettdan gंgitan semt)

Mama : Di mana tad Jihan diggit?

Jihan:Di situ nah Jihan main-main tad.

Mama : Kashannya. Sini mama kash minyak biar sembuh

Informasi tuturan:

Dituturkan oleh Jihan kepada Mama(Nenek). Jihan kesakitan karena digigit semut di kakinya.

Tuturan seperti dalam data (6) tersebut, anak juga telah menerapkan pragmatik fungsi interaksional untuk saling mencurahkan perasaan pemikiran dengan orang lain (neneknya). Interaksi antara anak dengan nenek tersebut telah berjalan dengan baik. Selain itu, dalam tuturan Mama kaki jihan sakit menunjukkan bahwa anak menggunakan tindak ilokusi, yakni selain menginformasikan kakinya yang sakit sekaligus merupakan permintaan agar mendapat pertolongan nenek.

Berdasarkan kedua data tersebut ditunjukan bahwa anak itu telah mampu menggunakan fungsi interaksional dengan baik. Hal itu membuktikan bahwa anak usia 2,5 tahun memungkinkan untuk belajar dan menggunakan fungsi interaksional. Fungsi pragmatik interaksional untuk saling mencurahkan perasaan pemikiran antara seseorang dan orang lain dapat distimulasi dalam diri anak. Peran mitra tutur dewasa terutama orang tua harus mampu menstimulasi anak untuk dapat mengungkapkan bahasa yang berfungsi interaksional.

\section{Fungsi personal}

Fungsi personal muncul saat seseorang menggunakan bahasa untuk mencurahkan perasaan dan pikiran. A nak-anak dalam interaksi sehari-hari, terutama dengan orangtua, sering mencurahkan perasaan dan pikirannya tentunya sesuai dengan taraf perkembangan berpikir anak. Berikut ini 
beberapa data tuturan yang menunjukkan adanya penggunaan fungsi personal dalam tuturan Jihan.

6) Ayah: Jihan, pensilnya bava sini.

Jihan: Ini punya Jihan

Ayah: Mau buat apa itu?

Jihan: Jihanmautulistulis Ayah Jihan mau bikin balon Kaya di kast.

Informasi tuturan:

Tuturan antara Ayah dan Jihan. Ayah meminta pensil yang dipegang Jihan sambil mondar-mandir. Jihan tidak mau menyerahkan. Jihan menyampaikan ke Ayah bahwa dia mau membuat gambar balon seperti di film yang baru saja dia tonton.

Seperti tuturan dalam data (7) tersebut, anak itu telah mengalami perkembangan pragmatik fungsi personal ketika telah mampu mencurahkan perasaan dan pikiran. D alam tuturan tersebut, anak mampu mencurahkan perasaan dan pikiran dengan mengatakan Jihan mau tulistulis Ayah, Jihan maubikinbalonkayadi kast. Pengungkapan keinginan seperti yang dilakukan anak itu merupakan bentuk fungsi personal sesuai dengan taraf berpikir anak-anak. Tuturan tersebut juga termasuk tindak lokusi karena tuturan itu merupakan bentuk anak menyatakan sesuatu yang bersifat informatif.

Tuturan lain yang juga menunjukkan adanya penggunaan fungsi personal anak terdapat dalam data berikut ini.

\section{7) Jihan: Capk Jihan}

Papa: Kenapa Jihan capke?

Jihan: Jihan tadi jalanjalan Teus Jihan mainmain Di situ tadi, di atas.

Informasi tuturan:

Tuturan antara Jihan dan Papa (Kakek) di kamar. Jihan mengeluh capak setelah bermainmain di wahana di mal.

Seperti dalam tuturan (8) tersebut, anak itu juga menggunakan bahasa pragmatik fungsi personal untuk menceritakan alasan capak dengan mengatakan Jihan tadi jalan-jalan. Terus Jihan mainmain Di situ tadi, di atas. Secara pragmatik apa yang dituturkan anak menyatakan dirinya capak karena jalan-jalan dan bermain dilakukan bersamaan. Tuturan tersebut juga termasuk tindak lokusi menyatakan sesuatu yang hanya bersifat informatif.

D alam kedua data tersebut ditunjukkan bahwa anak usia 2,5 tahun itu dapat menggunakan bahasa pragmatik fungsi personal dengan baik. $\mathrm{Hal}$ itu pula dapat menjadi pembuktian bahwa anak usia 2,5 tahun dapat memiliki penguasaan bahasa fungsi personal dengan baik. Tuturan-tuturan anak itu juga termasuk tindak lokusi menyatakan sesuatu yang bersifat informatif. Tingkat informatif tuturan yang disampaikan tentunya sesuai dengan taraf berpikir anak. Tuturan personal yang diungkapkan anak merupakan bentuk pengungkapan gagasan dan pengalaman. Bagi penutur dewasa, apa yang disampaikan anak itu seringkali dianggap tidak penting. Sebaliknya, sesuai dengan taraf perkembangan anak, tuturan-tuturan itu begitu penting bagi anak. A nak ingin berbagi cerita dan informasi. Faktanya, sering kali anak kecewa karena orang dewasa dianggap tidak bisa menjadi pendengar yang baik. Oleh karena itu, upaya mitra tutur dewasa untuk menunjukkan respons dan ketertarikan ketika anak berbicara menggunakan fungsi personal bahasa dapat menjadi stimulus perkembangan bahasa anak.

\section{Fungsi Heunistik}

Fungsi heuristik merupakan penggunaan bahasa untuk mengungkapkan tabir fenomena dan keinginan mempelajarinya. Penggunaan bahasa fungsi heuristik dapat berkembang pada masa anak-anak. Rasa ingin tahu yang besar dalam diri anak menstimulasi anak untuk mempelajari sesuatu. Berikut ini analisis data percakapan antara anak dan orang tua yang menerapkan fungsi heuristik. 
8) Ayah: (Mengrap dan mengluarkan air mata). Jihan: Kenapa Ayah?

Ayah: Ndak papa. Sudah Jihan bobo Jihan: Ayah kenapa?

Ayah: Ayah ndak papa Nak. Tad Ayah nguap karena Ayah ngantuk betul makanya kduar air mata.

Jihan: Ayah ndak ptpa?

Ayah: Ndak papa Sudah, Ayo bobo

Informasi tuturan:

Tuturan antara Ayah dan Jihan. Jihan penasaran kenapa Ayah mengeluarkan air mata. Jihan mengira Ayah menangis.

Tuturan seperti dalam data (9) tersebut menunjukkan bahwa anak itu telah mengalami perkembangan pragmatik fungsi heuristik. Anak itu penasaran saat melihat orang tuanya meneteskan air mata. A nak itu mengira ayah (orang tuanya) sedang menangis. Anak itu menanyakan alasan orang tuanya menangis dengan mengatakan kenapa Ayah (menangis)? Setelah mendapat jawaban yang tidak memuaskan, anak itu kembali bertanya Ayah kenapa? Setelah mendapat jawaban yang menurutnya jelas dan memastikan orang tuanya tidak apaapa dan tidak menangis, anak itu memastikan lagi dengan mengatakan Ayahndak papa?Penggunaan tuturan anak tersebut mengambarkan bentuk penggunaan bahasa anak yang berupaya mengungkapkan tabir fenomena dan adanya keinginan untuk mempelajari dan mengetahui sesuatu. Selain itu, tuturan termasuk tindak lokusi dengan menyatakan sesuatu yang bersifat informatif.

Berikut ini data yang juga menunjukkan perkembangan pragmatik fungsi heuristik pada anak.

9) Ayah: Mari Pak. (meryapa SatpamPeumahan) Jihan: Bapak siapa itu, Ayah?

Ayah: Bapak anaknya. (bacanda).

Jihan: Bapak anaknya? (Bingung.

Ayah: Iya, Bapak anaknya. Bapaknya itu jadi satpam Paham Jihan?
Jihan: Paham (Meki mash telihat lingung.

Informasi tuturan:

Tuturan antara Ayah dan Jihan saat melewati pos satpam gerbang perumahan. Jihan menanyakan perihal 'Bapak' yang disapa Ayah.

Seperti tuturan dalam data (10) tersebut, anak juga telah menjalankan fungsi heuristik. Pada tuturan tersebut, anak melontarkan pertanyaan Bapak siapaitu, Ayah?K arena jawaban dirasa belum pas dan memuaskan, anak kembali bertanya Bapak anaknya? Sebenarnya anak masih ingin melontarkan pertanyaan, tetapi karena disela dengan pertanyaan balik dari Ayah (orang tua) PahamJihan? Anak pun mengakhiri pertanyaannya. D alam lingkup tindak tutur, tuturan anak itu termasuk lokusi, yakni tindak tutur untuk menyatakan sesuatu yang bersifat informatif.

Pada kedua data tersebut ditunjukkan bahwa anak itu telah dapat mempelajari dan menggunakan fungsi heuristik dengan baik. Hal itu sekaligus membuktikan bahwa perkembangan pragmatik bahasa dalam fungsi heuristik dapat dipelajari dan digunakan dengan baik oleh anak usia 2,5 tahun. Fungsi heuristik dalam diri anak dapat berkembang baik apabila dalam komunikasi sehari-hari mendapatkan mitra tutur yang baik. Anak-anak memiliki rasa ingin tahu yang besar dan sering diungkapkan kepada mitra tutur yang dewasa terutama orang tua. Sayangnya, anak justru mendapati mitra tutur yang menganggap anak cerewet dan terlalu banyak bertanya. Bahkan, orang tua banyak yang berbuat kesalahan dengan meminta anak diam dan tidak banyak bertanya. Akibatnya, hal itu akan menumpulkan potensi anak mengembangkan fungsi heuristik bahasanya.

\section{Fungsi Imajinatif}

Fungsi imajinatif merupakan penggunaan bahasa untuk mengungkapkan imajinasi seseorang dan gambaran-gambaran tentang temuan seseorang yang tidak sesuai dengan realita (dunia 
nyata). Pada masa anak-anak daya imajinasinya berkembang begitu pesat. Imajinasi anak tergambar juga dalam penggunaan bahasanya. Berikut ini penerapan fungsi imajinatif dalam penggunaan bahasa Jihan.

10) Jihan: Ibu, Ibu. Jihan mau suap. (pura-pura meryapkan makanan)

Ilau : Apa ini Jihan (Purapura mengunyah). Jihan: Nasi goreng Jihan bikin nasi goreng (Mengaduk-aduk botd susu dengan sendk).

Ibu : Ehm. Enaknya.

Jihan: Enak kan!

Informasi tuturan:

Tuturan antara Jihan dan Ibu. Jihan main masak-masakan dan pura-pura menyuapi Ibu.

D unia anak memang penuh dengan imajinasi. Anak sering berimajinasi ketika bermain. Orang tua selayaknya berusaha untuk memahami imajinasi anak. Salah satu bentuk imajinasi anak terlihat dalam tuturan seperti data (10) di atas. Tuturan dalam data (10) tersebut menunjukkan bahwa anak itu telah mampu menjalankan fungsi imajinatif. Anak itu berimajinasi dengan mengatakan Ibu, Ibu, Jihan mau suap nasi greng Jihan bikin nasi greng dan tuturan selanjutnya Enak kan! D alam tuturan tersebut, anak itu berimajinasi dengan membuat nasi goreng serta menyuapi ibunya. Anak itu berimajinasi bahwa nasi goreng yang dibuat rasanya enak. Berdasarkan analisis tersebut si anak telah mampu menggunakan bahasa untuk mengungkapkan imajinasinya dan menggambarkan tentang temuan anak itu yang tidak sesuai dengan realita (dunia nyata). Tuturan tersebut juga masuk dalam kategori tindak lokusi karena menyatakan sesuatu dan hanya bersifat informatif.

Berikut ini data yang juga menunjukkan adanya penggunaan fungsi imajinatif Jihan dalam sebuah interaksi sosial.
11) Ayah: Jihan, lihatin Ayah (Meryusun lego)
Jihan: Ayah bikin apa?

Ayah:Ayah bikin hotd. Ini hotd punya Ayah

JihanNdak, ini hotd Jihan (medaut)

Ayah: Itu hotd Jihankah?

Jihan: Iya. Hotd Jihan tingg் betul. Jihan punya hotd sama mal.

Informasi tuturan:

Tuturan antara Ayah dan Jihan saat bermain lego.

Seperti tuturan dalam data (12) tersebut, anak itu telah mampu menjalankan fungsi imajinatif. Anak itu mengungkapkan imajinasinya pada saat bermain lego. Saat bermain menyusun lego, anak berminajinasi kelak dewasa nanti akan mempunyai hotel yang tinggi. Anak itu berimajinasi mempunyai hotel yang terpadu dengan mal. Tuturan tersebut merupakan imajinasi anak yang direpresentasikan dalam bentuk imajinatif bahasa. Tuturan anak itu juga termasuk kategori tindak lokusi untuk menyatakan imajinasi yang bersifat informatif.

Berdasarkan analisis kedua data tersebut, fungsi imajinatif dalam perkembangan bahasa pragmatik anak mampu seiring dengan perkembangan imajinasi dalam diri anak. Masa anak-anak merupakan waktu emas berkembangnya imajinasi anak dengan baik. D emikian pula fungsi imajinatif bahasa akan berkembang dengan baik mengikuti perkembangan imajinasi anak. Oleh karena itu, perkembangan bahasa pragmatik fungsi imajinatif pada anak dapat berkembang dengan baik dan lebih cepat dibandingkan fungsi-fungsi yang lain.

\section{Fungsi Representasional}

Fungsi representasional merupakan pengunaan bahasa untuk menggambarkan pemikiran dan wawasan serta menyampaikannya pada orang lain. Pada usia 2,5 tahun anak sudah mulai memiliki referensi terkait dengan wawasan dan pemikiran. Penguasaan bahasa yang baik dibutuhkan agar dapat mengungkapkan pemikiran dan wawasan kepada orang lain. Berikut ini tuturan 
dalam percakapan Jihan dengan orang tua yang menunjukkan adanya penggunaan fungsi representasional.

\section{2) Ayah: Jihan mau es krimkah?}

Jihan: Ndak mau

Ayah: Kenapa Jihan ndak suka es kim?

Jihan: Ncak mau Ayah Ndak mau

Ayah: Iya kenapa?

Jihan: Jihan sakit nanti. Pusing Ayah aja.

Informasi tuturan:

Tuturan antara Ayah dan Jihan. Ayah menggoda Jihan memberi es krim. Jihan pernah sakit hampir seminggu lebih gara-gara makan es krim.

Seperti tuturan dalam data (13) tersebut, anak telah menggunakan fungsi representasional bahasa. Hal itu ditunjukkan dalam penggalan tuturan Jihan sakit nanti, pusing Ayah aja. Tuturan anak tersebut menyampaikan pemikiran dan wawasan tentang es krim. Anak itu sering sakit karena makan es krim. Anak itu pun berkesimpulan mengonsumsi es krim akan menyebabkan dirinya sakit. Tuturan tersebut muncul sebagai akibat adanya wawasan dan pemikiran anak mengenai suatu kejadian. Tuturan anak tersebut juga termasuk tindak lokusi untuk menyatakan sesuatu dan bersifat informatif.

Tuturan lain yang juga menunjukkan adanya fungsi representasional tuturan anak terdapat dalam data berikut ini.

\section{3) Jihan : Ibu, Ibu lihat (sambil nunjuk mal)}

Ibu: Itu mal.

Jihan : Iya. Itu buat notton Jihan pemah Jihan nonton sama Ayah, sama Ilou

\section{Ibu : Iya. Nanti kapankkapan nonton lag.}

Informasi tuturan:

Tuturan antara Jihan dan Ibu di dalam mobil ketika melewati salah satu mal. Di mal tersebut, beberapa minggu sebelumnya, Jihan bersama Ayah dan Ibu menonton film di bioskop.
Tuturan seperti dalam data (14) tersebut, menunjukkan bahwa anak itu juga telah menggunakan fungsi representasional bahasa. Anak itu menyampaikan wawasan dan pengalamannya yang pernah menonton film bioskop di salah satu mal. Ketika melewati mal, anak itu menyampaikan bu, Ibu lihat, dan ya, itu buat notton Jihan pemah, Jihan monton sama Ayah, sama lbu Tuturan tersebut merupakan hasil dari wawasan anak mengenai suatu objek dan mengungkapkannya kepada orang lain. Tuturan anak itu juga termasuk kategori tindak lokusi untuk menyatakan sesuatu dan bersifat informatif.

Kedua data tersebut menunjukkan pengalaman atau wawasan anak sangat membantu dalam khasanah kebahasaan. Anak dapat memiliki pemikiran apabila sebelumnya ada referensi atau wawasan pada masa lalu yang kemudian diungkapkan dalam penggunaan bahasa. Rasa ingin tahu dalam diri dapat membantu anak mengungkapkan pemikiran pada waktu selanjutnya.

Berdasarkan analisis fungsi-fungsi pragmatik (penggunaan bahasa) dalam tuturan Jihan yang berusia 2,5 tahun saat berinteraksi dengan anggota keluarga dapat dipahami peran lingkungan sosial sangat berpengaruh terhadap pesatnya perkembangan bahasa anak. Hal itu selaras dengan pandangan Halliday bahwa anak belajar bahasa dalam rangka sosialisasi dan mengarahkan perilaku orang lain agar sesuai dengan keinginannya. Anak selain belajar bentuk dan arti bahasa, juga termotivasi oleh fungsi bahasa yang dapat diperoleh. Jihan merupakan salah satu kasus anak yang pada usia 2,5 tahun telah mencapai tahapan penggunaan bahasa pada keseluruhan fungsi. Tentunya penggunaan fungsi-fungsi tersebut sesuai dengan tingkat pemahaman anak.

Khusus pada periode diferensiasi $(2,5-5$ tahun), merupakan masa Jihan melakukan diferensiasi dalam penggunaan kata-kata dan kalimat- 
kalimat. Bahasa anak itu berkembang dengan baik, secara kuantitatif maupun kualitatif. Fungsi bahasa untuk komunikasi betul-betul mulai berfungsi. Anak itu sudah dapat mengadakan konversi dengan cara yang dapat dimengerti oleh orang dewasa. Persepsi anak terhadap pengalamannya tentang dunia luar mulai ingin dibaginya dengan orang lain dengan cara memberikan kritik, bertanya, menyuruh, memberi tahu, dan lain-lain.

A pabila dikaitkan dengan teori dan hasil penelitian terdahulu, penguasaan fungsi pragmatik Jihan bisa dinyatakan memiliki kemampuan di atas rata-rata anak usia 2,5 tahun. Terpenuhinya semua fungsi penggunaan bahasa Jihan merupakan gambaran nyata pesatnya perkembangan bahasa anak. Hal itu jauh lebih baik apabila dibandingkan dengan hasil penelitian untuk tingkatan SD yang rata-rata baru sebatas interaksional dan heuristik. Pencapaian gemilang tersebut sangat dimungkinkan oleh pengaruh biologis dengan ayah dan ibu (orang tua) yang memang memiliki kemampuan berbahasa yang baik. Selain itu, pengaruh lingkungan sosial rumah dan sekolah (Taman Penitipan Anak).

Hal itu sesuai dengan pandangan Tarigan, adanya dua persyaratan dasar yang memungkinkan seseorang mampu menerapkan fungsi-fungsi penggunaan bahasa dengan baik. Persyaratan pertama, adanya potensi faktor biologis yang dimiliki sang anak, dan persyatan kedua, adanya dukungan sosial yang diperoleh anak. Faktor biologis berkenaan dengan faktor turunan dari orang tua yang memiliki kemampuan berbahasayang baik menjadi modal utama. Potensi tersebut dapat berkembang baik dengan ditunjang dukungan sosial yang mampu menstimulasi perkembangan bahasa anak (Jihan). Lingkungan sosial menjadi contoh nyata Jihan belajar fungsi pragmatik (penggunaan bahasa). Lingkungan di sekitar Jihan menjadi sarana efektif sebagai objek belajar. Peran guru dan orang tua memberikan sumbangan terbentuknya ling- kungan yang positif bagi perkembangan fungsi penggunaan bahasa Jihan.

\section{PENUTUP}

Berdasarkan analisis dan pembahasan dapat disimpulkan bahwa Jihan pada usia 2,5 tahun telah mencapai tahapan penggunaan bahasa pada keseluruhan fungsi pragmatiknya, yakni fungsi instrumental, fungsi regulatoris/ dogmatis, fungsi interaksional, fungsi personal, fungsi heuristik, fungsi imajinatif, dan fungsi representasional. Dalam menggunakan semua fungsi tersebut, tuturantuturan Jihan dapat dikategorikan tindak lokusi dan ilokusi. Penguasaan bahasa pragmatik anak tersebut bisa dinyatakan memiliki kemampuan di atas rata-rata anak usia 2,5 tahun.

Terpenuhinya semua fungsi bahasa merupakan gambaran nyata pesatnya perkembangan bahasa Jihan apabila dibandingkan dengan hasil penelitian untuk tingkatan SD yang baru sebatas interaksional dan heuristik. Pencapaian gemilang tersebut dipengaruhi faktor biologis dari ayah dan ibu yang memiliki kemampuan berbahasa yang baik. Selain itu, pengaruh lingkungan so sial, rumah, dan Taman Penitipan Anak (TPA).

Peran lingkungan sosial terbukti sangat berpengaruh terhadap pesatnya perkembangan bahasa seorang anak. Anak belajar bahasa dalam rangka sosialisasi dan mengarahkan perilaku orang lain agar sesuai dengan keinginannya. Anak selain belajar bentuk dan arti bahasa, juga dapat termotivasi oleh fungsi bahasa yang dapat diperoleh. Jihan merupakan salah satu contoh kasus anak yang pada usia 2,5 tahun telah mencapai tahapan penggunaan bahasa pada keseluruhan fungsi. Tentunya penggunaan fungsi-fungsi tersebut sesuai dengan tingkat pemahaman anak. Stimulasi yang terus- menerus dilakukan keluarga dan lingkungan sosial lainnya dapat saling melengkapi dan menunjang perkembangan fungsi pragmatik bahasa anak. 


\section{DAFTAR PUSTAKA}

Artikel D unia Anak. 2015. Pentingnya Pendidikan Anak Usa Dini http:/ / belajarpsikologi.com/ pentingnya-pendidikan-anak-usia-dini/ . D iakses 13 Februari 2015.

Mar'at, S. 2011. Psikdinguistik: Suatu Pengantar. Bandung: Ferika Aditama.

Miles, M. B., \& Huberman, A. M. 1992. Analisis Data Kualitatif (T. R. (Penerjemah) Rohidi, Ed.) (I). Jakarta: Penerbit Universitas Indonesia.

Moleng, L. J. 1994. Metoddog Penditian Kualitatif (25th ed.). Bandung: PT Remaja Rosdakarya.

Mulyana, D. 2010. Metode Penditian Kualitatif. Bandung: PT Remaja Rosdakarya.

Mulyasa, H. E. 2012. ManajemenPAUD. Bandung: Remaja Rosdakarya.

Pusat Pengembangan Profesi Pendidik. 2012. Modul Karakteristik Pekkembangan Bahasa Anak. Jakarta.

Sudartinah, T. 2010. Analisis Pragnatik tehadap Tututran Anak Usia Dua Tahun (Studi Kasus pada Shihab Fatin Alvan). Yogyakarta.

Sujiono, Y. N. dan B. S. 2010. Bermain Kreatif Bedbasis Keeedasan Jamak. Jakarta: Indeks.

Tarigan, H. G. 2011. Pengajaran Pemeddhan Bahasa Bandung: Angkasa.

Yusuf, S. 2009. Psikdog Pekembangan Anak \& Remaja Bandung: Remaja Rosdakarya. 